\title{
Beemer-Ertbruggen syndrome
}

INSERM

\section{Source}

INSERM. (1999). Orphanet: an online rare disease and orphan drug data base. BeemerErtbruggen syndrome. ORPHA:1237

Beemer-Ertbruggen syndrome is a lethal malformation syndrome reported in 2 brothers of first-cousin parents that is characterized by hydrocephalus, cardiac malformation, dense bones, and unusual facies with down-slanting palpebral fissures, bulbous nose, broad nasal bridge, microg nathia and a long upper lip. There have been no further descriptions in the literature since 1984. 